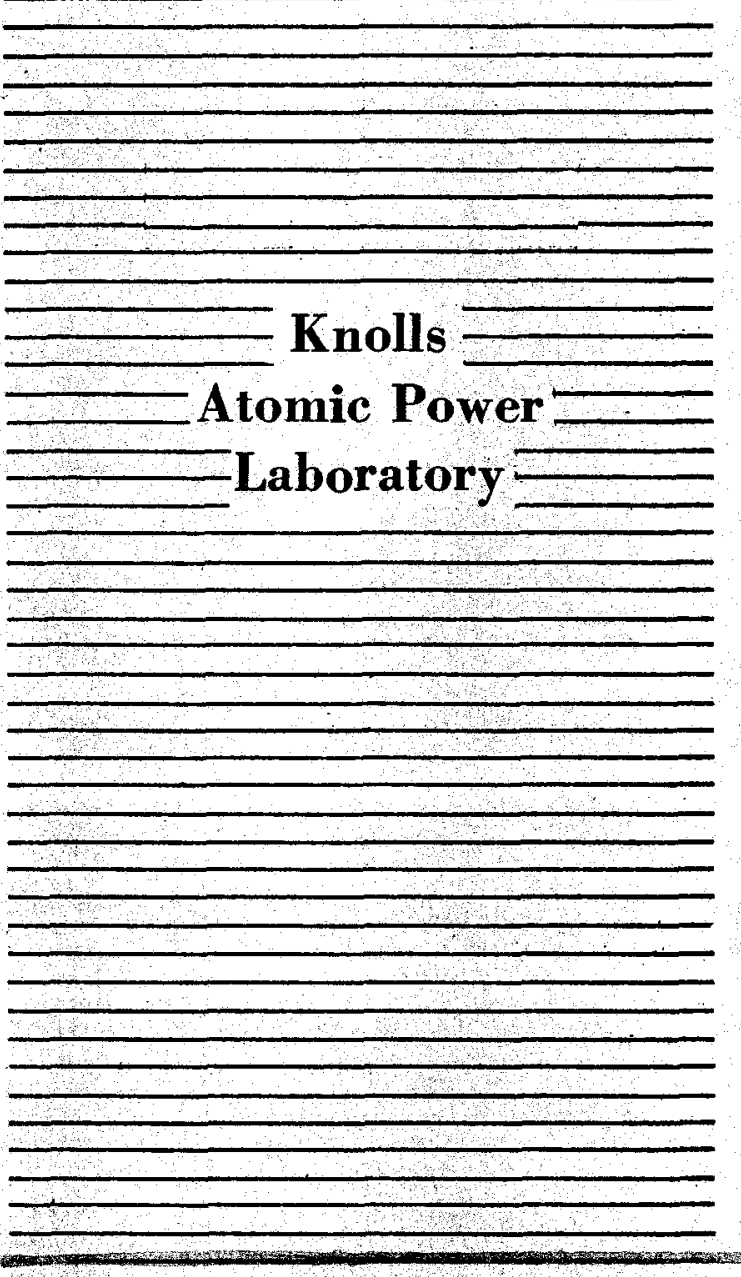

\title{
The Effects of
}

\section{Transients and Longer-Time Anneals on Irradiated Uranium-Zirconium Alloys}

Operated for the United States Atomic

GENERAL (G9) ELCTRIC Energy Commission by 


\section{DISCLAIMER}

This report was prepared as an account of work sponsored by an agency of the United States Government. Neither the United States Government nor any agency Thereof, nor any of their employees, makes any warranty, express or implied, or assumes any legal liability or responsibility for the accuracy, completeness, or usefulness of any information, apparatus, product, or process disclosed, or represents that its use would not infringe privately owned rights. Reference herein to any specific commercial product, process, or service by trade name, trademark, manufacturer, or otherwise does not necessarily constitute or imply its endorsement, recommendation, or favoring by the United States Government or any agency thereof. The views and opinions of authors expressed herein do not necessarily state or reflect those of the United States Government or any agency thereof. 


\section{DISCLAIMER}

Portions of this document may be illegible in electronic image products. Images are produced from the best available original document. 
UC-25, Metallurgy and Ceramics (TID-4500, 13 Edition, Rev。)

THE EFFECT OF TRANSIENTS AND LONGER TIME ANNEALS ON IRRADIATED URANIUM-ZIRCONIUM ALLOYS

William V. Johnston

October 3, 1958
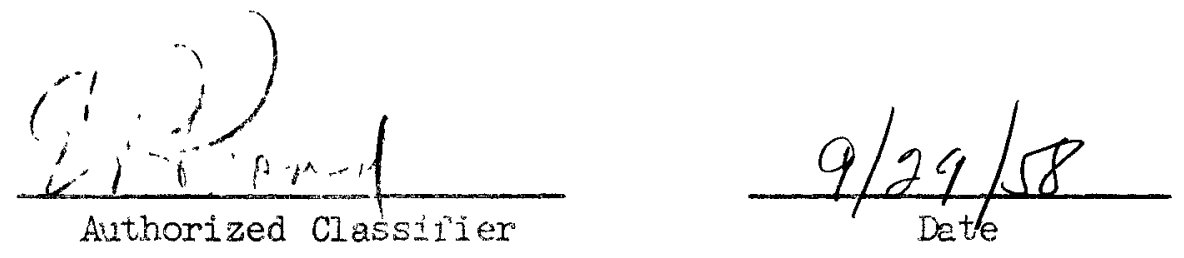

\author{
Knolls Atumic Power Laboratory \\ General Electric Company \\ Schenectady, New York \\ Operated for the \\ United States itomic Energy Commission \\ Contract 1No. W-31-109 Eng-52
}




\section{LEGAL NOTICE}

This report was prepared as an account of Government sponsored work. Neither the United States, nor the Commission, nor any person acting on behalf of the Commission:

A. Makes any warranty or representation, express or implied, with respect to the accuracy, completeness, or usefulness of the information contained in this report, or that the use of any information, apparatus, method, or process disclosed in this report may not infringe privately owned rights; or

B. Assumes any liabilities with respect to the use of, or for damages resulting from the use of any information, apparatus, method, or process disclosed in this report.

As used in the above, "person acting on behalf of the Commission" includes any employee or contractor of the Commission to the extent that such employee or contractor prepares, handles or distributes, or provides access to, any information pursuant to his employment or contract with the Commission.

Price .75 cents. Available from the Office of Technical Services, Department of Commerce, Washington 25, D。C. 


\section{KAPL-1965}

UC-25, Metallurgy and Ceramics (TID-4500, 13 Edition, Rev.)

Internal Distribution

No. of Copies

AEC, SNROO

1

Anderson, JD

1

Allio, RJ

Altamarie, LA

1

Anderson, WK

Barney, WK

1

Beard, AP

$\mathrm{Bibb}, \mathrm{AE}$

Cashin, WM

Document Iibrary

Douglass, DL

Glasson, $\mathrm{TJ}$

Hilderbrand, RD

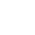

Johnston, WV

Krastins, G

Kunz, FW

Lacy, CE

LaRocque, DD

Leavy, EA

Leipsiger, FD

Margulis, W

Noonan, JE

SAR File

Schmidt, CJ-TIG File

Sears, MJ

Seymour, WE

Sims, CT

Trott, BD

Weber, CE

Wemple, BD

Willis, $\mathrm{AH}$

Wollam, JS

1

1

1

1

3

1

1

1

20

1

1

1

1

1

1

1

I

1

5

1

1

1

1

1

1

1

External Distribution

Aberdeen Proving Ground 2

AEC Scientific Representative, Argentina 1

AEC Scientific Representative, France 1

AEC Scientific Representative, Japan 1 
$\underline{\text { KAPL-1965 }}$

External Distribution (continued)

№. of Copies

Alco Products, Inc.

Argonne National Laboratory

10

Armed Services Technical Information Agency

Army Ballistic Missile Agency

1

Atomic Energy Commission, Washington 3

Atomics International

Babcock \& Wilcox Company

Battelle Memorial Institute

Bettis Plant

Boeing Airplane Company

Brookhaven National Laboratory

Brush Beryllium Company

Bureau of Ships (Code 1500)

Canel Operations

Chicago Patent Group

Columbia University (Dr。 Hassialis)

Combustion Engineering, Inc.

Consolidated Vultee Aircraft Corporation

Convair-General Dynamics

Curtiss-Wright Corporation

Defence Research Member

Department of Food Technology (MIT)

Department of Navy (Code 422)

2

4

Department of the Army, G-2

Division of Raw Materials, Denver

Dow Chemical Company (Rocky Flats)

Du Pont de Nemours and Company, Aiken

Du Pont de Nemours and Company, Wilmington

Evans Signal Laboratory

Frankford Arsenal

General Electric Company (ANPD)

General Electric Company, Richland

General Nuclear Engineering Corporation

Goodyear Atomic Corporation

Iowa State College

Jet Propulsion Laboratory

Kirtland Air Force Base

Iockheed Aircraft Corporation (Bauer)

2

Ios Alamos Scientific Laboratory

Mallinckrodt Chemical Works 
KAPL-1965

External Distribution (continued)

No. of Copies

Maritime Administration I

Metals and Controls Corporation . I

Mound Laboratory 1

National Advisory Committee for Aeronautics, Cleveland I

National Bureau of Standards, Atomic Energy Project 2

National Bureau of Standards (Iibrary) I

National Lead Company, Inc., Winchester 1

National Lead Company of Chio 2

Naval Research Laboratory 3

New Brunswick Area Office 1

New York Operations Office 2

Muclear Development Corporation of America I

Nuclear Metals, Inc. 1

Dak Ridge Institute of Nuclear Studies 1

Oak Ridge National Laboratory 6

Office of Naval Research 2

Office of Ordnance Research I

Oin Mathieson Chemical Corporation I

Ordnance Materials Research office I

Ordnance Tank-Automotive Command 1

Patent Branch, Washington 1

Phillips Petroleum Company 4

Picatinny Arsenal 1

RAND Corporation 1

Rensselaer Polytechnic Institute 1

Sandia Corporation, Albuquerque 2

Sylvania Electric Products, Inc. 1

Technical Research Croup 1

Tennessee Valley Authority 1

The Martin Company 1

Union Carbide Nuclear Company (ORGDP) 2

Union Carbide Nuclear Company (Paducah Plant) 1

U. S. Geological Survey, Denver 1

U. S. Geological Survey, Menlo Park 1

U. S. Geological Survey, Washington 1

U. S. Naval Postgraduate School 1

U. S. Patent Office 1

University of California Radiation Laboratory, Berkeley 2

University of California Radiation Iaboratory, Iivermore 2

University of Puerto Rico 1 


\section{UNCLASSIFIED}

External Distribution (continued)

No. of Copies

Vitro Engineering Division

Watertown Arsenal

Weil, Dr. George L.

Westinghouse Electric Corporation (Schafer)

Wright Air Development Center

Yankee Atomic Electric Company

Technical Information Service Extension, Oak Ridge

office of Technical Services, Washington
KAPI-1965

1

1

1

2

8

1

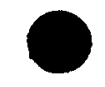

325

75 


\section{CONTENTS}

\section{Page}

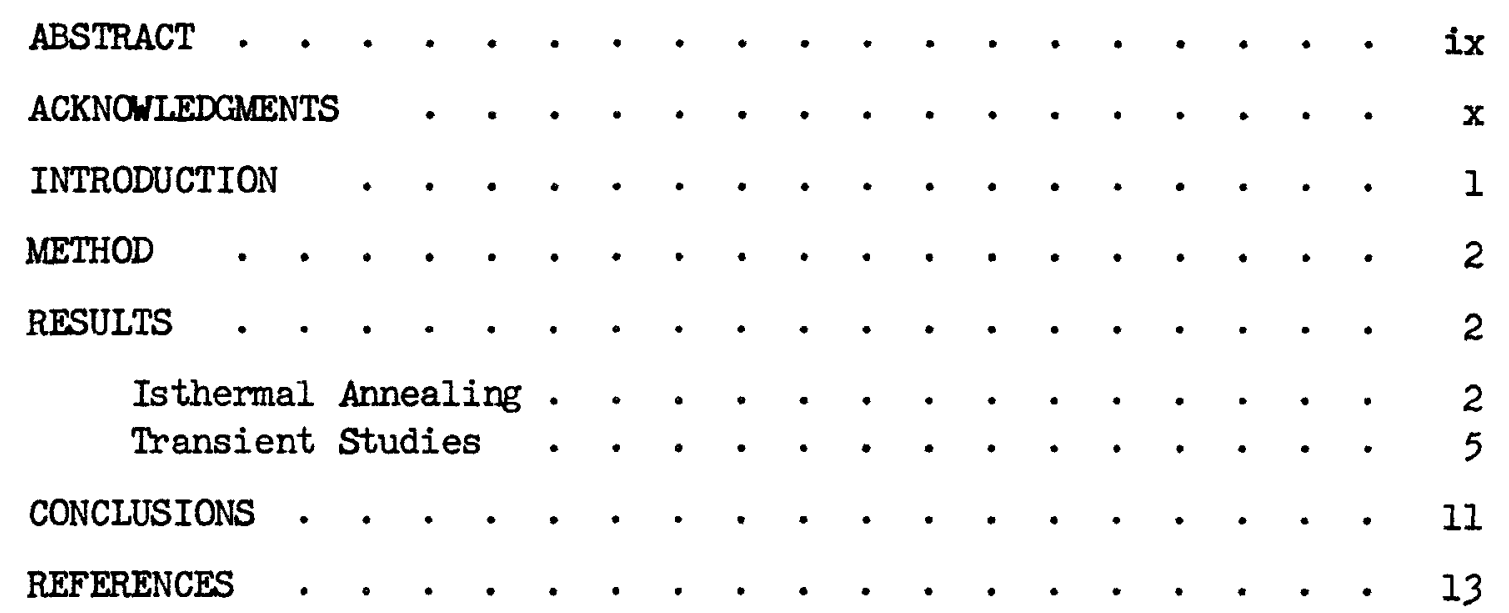


KAPI-1965

\section{ILLUSTRATIONS}

Equilibrium phase diagram for the U-Zr alloy system

$$
\text { (KS-20929) }
$$

The volume stability of 7-8 wt $\% \mathrm{U}-\mathrm{Zr}$ alloys in postirradiation annealing studies $(\mathrm{KS}-19794)$. . . • . 4

8 wt \% U- $\mathrm{Zr}$ alloy, annealed $500 \mathrm{hr}$ at $595^{\circ} \mathrm{C}$. As polished. (1000X)

8 wt \% U-Zr alloy, after 0.15 at. \% burnup and $500 \mathrm{hr}$ at $595^{\circ} \mathrm{C}$. As polished. $(1000 \mathrm{X})$. . . . . . 6

Carbon replica of 8 wt \% U-Zr alloy, after 0.15 at. \% burnup and 500-hr anneal at $595^{\circ} \mathrm{C}$. As polished. $(10,000 X)(K S-20930)$

8 wt \% U-Zr alloy, after 1.05 at. \% burnup and 500-hr anneal at $425^{\circ} \mathrm{C}$. As polished. (1000X) . . . . . 7

Carbon replica of 8 wt \% U-Zr alloy, after 1.05 at. \% burnup and 500-hr anneal at $425^{\circ} \mathrm{C}$. As polished. (20,000X) (KS-2093I)

8 wt $\% \mathrm{U}-\mathrm{Zr}$ alloy, after 1.15 at. $\%$ burnup and 500-hr anneal at $500^{\circ} \mathrm{C}$. As polished. (1000X) . . . . . . 8

98 wt \% U-Zr alloy, after 1.15 at. \% burnup and 500-hr anneal at $500^{\circ} \mathrm{C}$. As polished. Polarized light; light spots are void spaces (500X) . . . . . . . . . 8

10 Carbon replica of 8 wt $\% \mathrm{U}-\mathrm{Zr}$ alloy, after 1.15 at. \% burnup and $500 \mathrm{hr}$ at $510^{\circ} \mathrm{C}$. As polished. (18,000X) (KS-20932) • • • • • • • • • • • • • 8

118 wt $\%$ U-Zr alloy, after 1.25 at. \% burnup and 500-hr anneal at $595^{\circ} \mathrm{C}$. As polished. (1000X). Large void areas. . 9

12 Carbon replica of 8 wt $\% \mathrm{U}-\mathrm{Zr}$ alloy, after 1.25 at. \% burnup and $500 \mathrm{hr}$ at $595^{\circ} \mathrm{C}$. As polished. $(37,000 \mathrm{X})$ (KS-20933) • . • . . . . . . . . . 9

13 Volume stability of 7 wt \% U-2r alloy during 6-sec postirradiation temperature transient. (KS-20352) • • 10 


\section{ABSTRACT}

Small pieces of Zircaloy-clad 7 and 8 wt $\%$ uraniumzirconium alloys irradiated from 0.4 to 1.5 at. $\%$ burnup of the total core atoms in the MTR have been heat-treated at temperatures between 510 and $980^{\circ} \mathrm{C}$ for periods of time from $1 \mathrm{sec}$ to $500 \mathrm{hr}$. The resulting changes in density, electrical resistivity, and microstructure were observed.

The core volume changes were found to be a function both of temperature and time at temperature for a given burnup. A decrease in the swelling rate with time was observed. Thus, at $620^{\circ} \mathrm{C}$, about 40 per cent of the core volume charge after $300 \mathrm{hr}$ (37\%) occurred in the first $6 \mathrm{hr}$. At lower temperatures, more time was required for an equivalent fractional volume change.

Metallographic changes and gas bubble formation at phase boundaries were observed optically at temperatures as low as $510^{\circ} \mathrm{C}$ in high burnup material. Bubbles were also observed in the electron microscope.

The changes observed appear to be due to the growth of inert gas bubbles formed in the epsilon phase of uraniumzirconium alloy and also to a transformation occurring in the delta phase. The effect of irradiation temperature and flux on the nucleation and growth of the gas bubbles is discussed. 


\section{ACKNOWLEDGMENTS}

The success of any investigation of irradiated materials is dependent upon the help of a great number of people. The cooperation and helpfulness of the personnel of the Radioactive Materials Laboratory at KAPL should be given special recognition.

The author wishes to express his appreciation to the following individuals who contributed uniquely to this study: $B$ 。 Do Wemple for his excellent remote metallography; Dr。F。 Do Leipziger for his careful electron microscopic examination; J。 E. Noonan, E. A。 Bush, and R。 Do Hildebrand for the operation of the annealing facility and the calculations; L. A. Altamarie for his suggestions on equipment design which were of considerable help in simplifying the in-cell operation. 


\title{
THE EFFECT OF TRANSIENTS AND LONGER-TIME ANNEAIS ON IRRADIATED URANIUM-ZIRCONIUM ALIOY*
}

\author{
W. V. Johnston
}

\section{INTRODUCTION}

Fuel element swelling during irradiation at elevated temperature presents a serious technical problem to the development of high power density, mobile reactors as well as to the economical production of electric power. The use of small highly enriched cores, high temperature operation, and long life-the most desirable features of a naval reactor-are also features that will depend the most on the knowleage of the probable anounts and rates of fuel element physical changes.

The primary cause of these changes is believed to be the formation of bubbles or gas pockets within the fuel by the precipitation of the inert gases, krypton and zenon, which are produced as a result of the fission process. For a given fuei element geometry, the most important factors controlling this precipitation and growth process are thought to be the following:

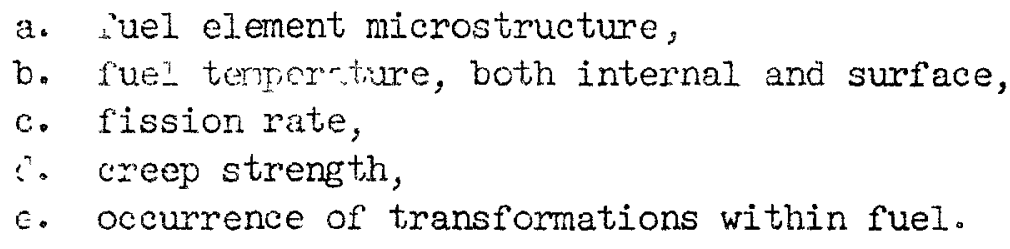

C. E. Weber in his paper presented earlier in this conference (sic) has summarized much of the past information on this subject and has considered some of the areas of future study. Therefore, we will proceed directly to the experiments in progress.

\footnotetext{
* This paper was prepared for presentation at the Gatlinburg Conference on Nuclear Fuel Element Technology, May 14-16, 1958. A complete review will be published when the work reported herein is finished.
} 
METHOD

In the fall of 1957, a new hot laboratory facility for postirradiation annealing and the measurement of physical property changes of irradiated and unnealed muclear fuel and poison materials was put into operation at KAPL. The information obtained through postirradiation annealing is to supplement the information obtained through in-pile irraoiations. The facility has provisions for measuring the amount and rate of release of fission gases during annealing as well as the changes in such physical properties as density, dimensions, and electrical resistivity.

IWo studies on uranium-zirconium alloy are in progress in this iacility, those on isothermal postirradiation annealing and on temperature transient effects. The annealing studies are designed to find the effects of burnup and temperature on the rate and amounts of sweliing of the irradiated U-Zr alloy. The temperature transient studies are designed to estimate the amount of damage that might occur to fuel elements should a reactor experience a power excursion during operation or startup. This means that the ruel elements must be heated to temperatures between 600 and $900^{\circ} \mathrm{C}$ in a few seconds and then quenched either to room temperature or to the normai reactor uposting temperatures. Changes in dimensions, electrical resistivity, and density were measured in these expeximents. The scuples were annealed for a time after the transient to see if any subsequent effects had appeared.

\section{RESULTS}

Isotherma Annealing

Ihe 7 and 8 wt 0 U-Zr alloys were annealed in vacuum or low pressure heifum for a total of $500 \mathrm{hr}$ at 510,540 , or $620^{\circ} \mathrm{C}$. The preirradiation heat-treatment $\left(30 \mathrm{~min}\right.$ at $720^{\circ} \mathrm{C}$ and furnace cooled) was such that the delta phase was a dispersion of about to 2- $\mu$ diam particles in the epsilon phase solia solution. The U- $\mathrm{Zr}$ pulase diagram ${ }^{1}$ is shown in Figure 1. The experimental material consisted of sections of 7 wt $\%$ U-Zr alloy, $1-1 / 2$ to 2 in. long, clad with 0.010 in. of Zircaloy-3. The ends were not clad and the core was thus exposed. The alloy had seven different burnups between 0.4 and 1.4 at. $\%$ or the total core atoms. The change in volume of the core is shown in Figure 2. Data for 8 wt $\% \mathrm{U}-\mathrm{Zr}$ alloy obtained at $595^{\circ} \mathrm{C}$ during some earlier work ${ }^{2}$ are plotted as dashed lines. Three things are to be seen from these results:

First: Saturation in the swelling is obtained in most samples after about $200 \mathrm{hr}$ of temperature. 


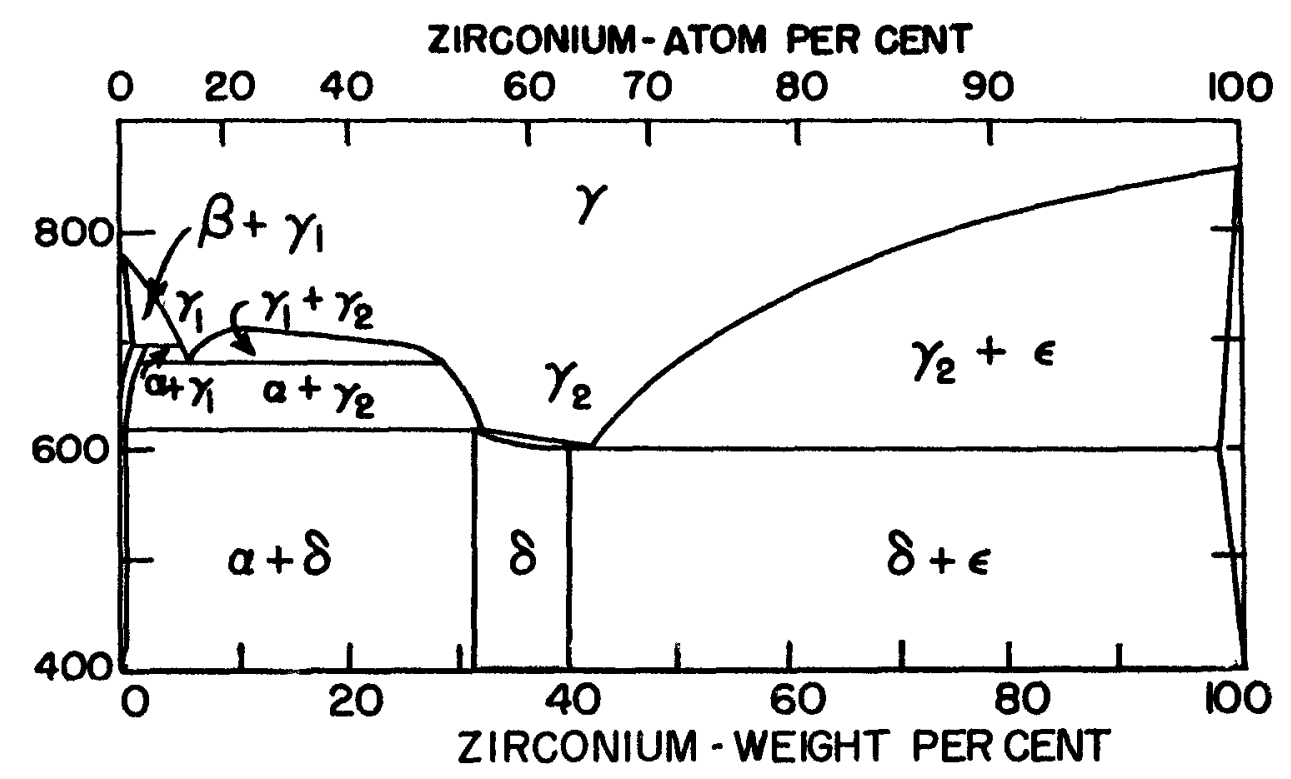

Figure 1. Equilibrium phase diagram for the U-Zr KS-20929 alloy system.

UNCLASSIF IED

Second: The samples appear to fall roughly into two groups:

a. A group annealed at the highest temperatures with $35 \%$ or greater swelling.

b. A group with $10 \%$ or less swelling that was annealed at $510^{\circ} \mathrm{C}$, plus some low burnup samples that were annealed at 540 and $595^{\circ} \mathrm{C}$. The 1.2 and 1.4 at.\% material heated at $540^{\circ} \mathrm{C}$ swelled to an amount intermediate to the other two, but is still rising at a rate that will take it into the upper group at about $1000 \mathrm{hr}$.

Third: Although the alloys with the most burnup swell most rapidly on initial heating, they have not necessarily swelled the most by the time saturation is reached.

These three effects must be taken into account when the data are interpreted. Additional information obtained from counting krypton-85 released during the anneals shows that only fractions of a per cent of the theoretical amounts of gas are released and that the rate of release does not follow the square root of time. Metallographic examination of this material 


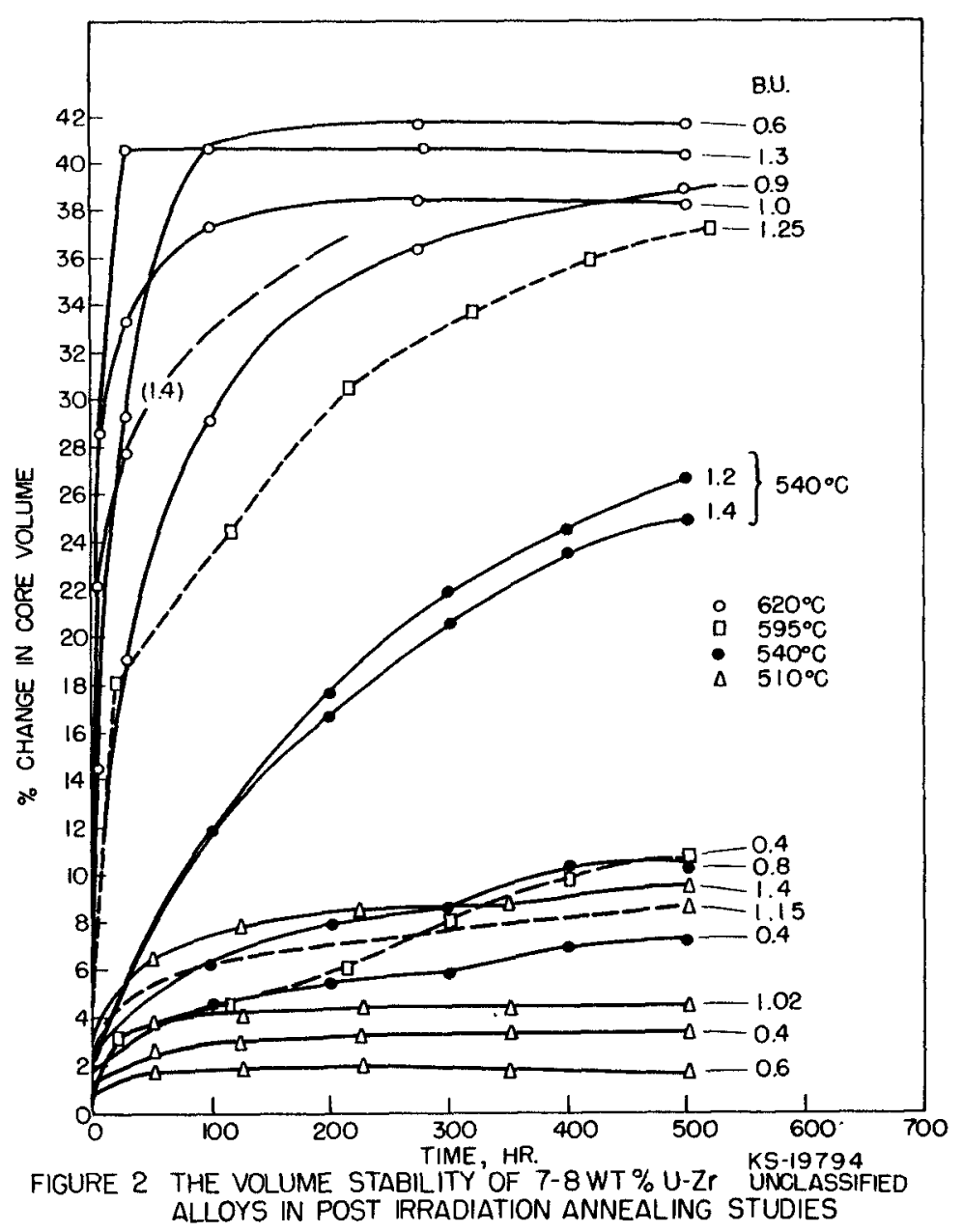

is just beginning and photographs are not yet available. However, examination of the 8 wt $\%$ alloy from which the data in Figure 2 were plotted has recently been completed. Both optical examination and electron microscopy have been used.

Figures 3, 4, 5 show what one might expect to see on unirradiated or low burnup material. The metallographic preparation consists of polishing with diamond paste moistened with oxalic acid to remove effects of coldwork. No etchant is used. Figure 3 shows unirradiated 8 wt \% U-Zr alloy after annealing at $595^{\circ} \mathrm{C}$. The second or delta phase is in the grain boundaries and is somewhat globular. Figure 4 shows porosity from irradiation to 0.1 at.\% burnup between 600 and $650^{\circ} \mathrm{C}$, followed by a 500-hr anneal at $595^{\circ} \mathrm{C}$. There was no volume change during annealing. The delta phase is still quite clearly visible in the photograph; in addition, a large amount of porosity has appeared 
in the sample. The same sample at magnification of 10,000 diameters is shown in Figure 5. The polystyrene balls, $0.37 \mu$ in diameter, were used to indicate the direction of the carbon shadowing. The markers seem to cluster at the location of major surface discontinuities. Since we look between such clusters at higher magnification, the electron microscope is actually looking at the epsilon phase. A large number of bubbles $0.1 \mu$ diam and smaller are also visible. This general pattern was observed to a greater or lesser degree in all the annealed alloys thus far studied.

The effect of annealing temperature on the microstructure of three 8 wt $\%$ alloys of approximately the same burnup is shown next. The alloy in Figure 6 had 1.05 at.\% burnup and was annealed at $425^{\circ} \mathrm{C}$. There was no volume change during annealing. The delta phase forms the boundary between subgrains and appears to be harder than the epsilon since it is above the plane of the sample. No porosity is evident at this magnification. Figure 7 shows the same sample at $20,000 \mathrm{X}$. We can now see large numbers of bubbles of size 0.01 to $0.10 \mu$.

Figure 8 shows an alloy of 1.15 at.\% burnup annealed at $510^{\circ} \mathrm{C}$. This sample swelled 5\% during annealing. The cladding formed twins in several places. The delta phase stands out more sharply at this temperature than at $425^{\circ} \mathrm{C}$. Under polarized light (in Figure 9), porosity, as evidenced by bright spots, can be seen in the boundaries.

The electron photomicrograph (Figure 10) shows somewhat fewer but larger bubbles; this possibly indicates growth of some bubbles at the expense of adjacent bubbles.

Figure 11 shows an alloy of 1.25 at.\% burnup which was annealed $500 \mathrm{hr}$ at $595^{\circ} \mathrm{C}$. This temperature is about $10^{\circ} \mathrm{C}$ below the unirradiated delta-gamma transformation and this sample swelled $31.7 \%$ during annealing. Porosity is evident throughout the sample. The delta phase appears to be the origin of the voids. There was considerable twinning in the cladding. Figure 12 shows the epsilon phase still containing bubbles and with some additional irregular eruptions which may be associated with the transformation.

\section{Transient Studies}

A program is in progress to study the effects of short duration, high temperature transients on the irradiation stability of 7 wt \% U-Zr alloy. This is being done by very rapid induction heating of small irradiated samples followed by a mercury quench. The heating times ranged from $1 / 2 \mathrm{sec}$ to $1 \mathrm{~min}$ and the temperature varied from 1200 to $1800^{\circ} \mathrm{F}$. The temperature was measured by means of a thermocouple spot-welded directly onto the sample. The results shown in Figure 13 were obtained, except where noted otherwise on the figure, from three successive 1-sec heatings to the desired temperature 

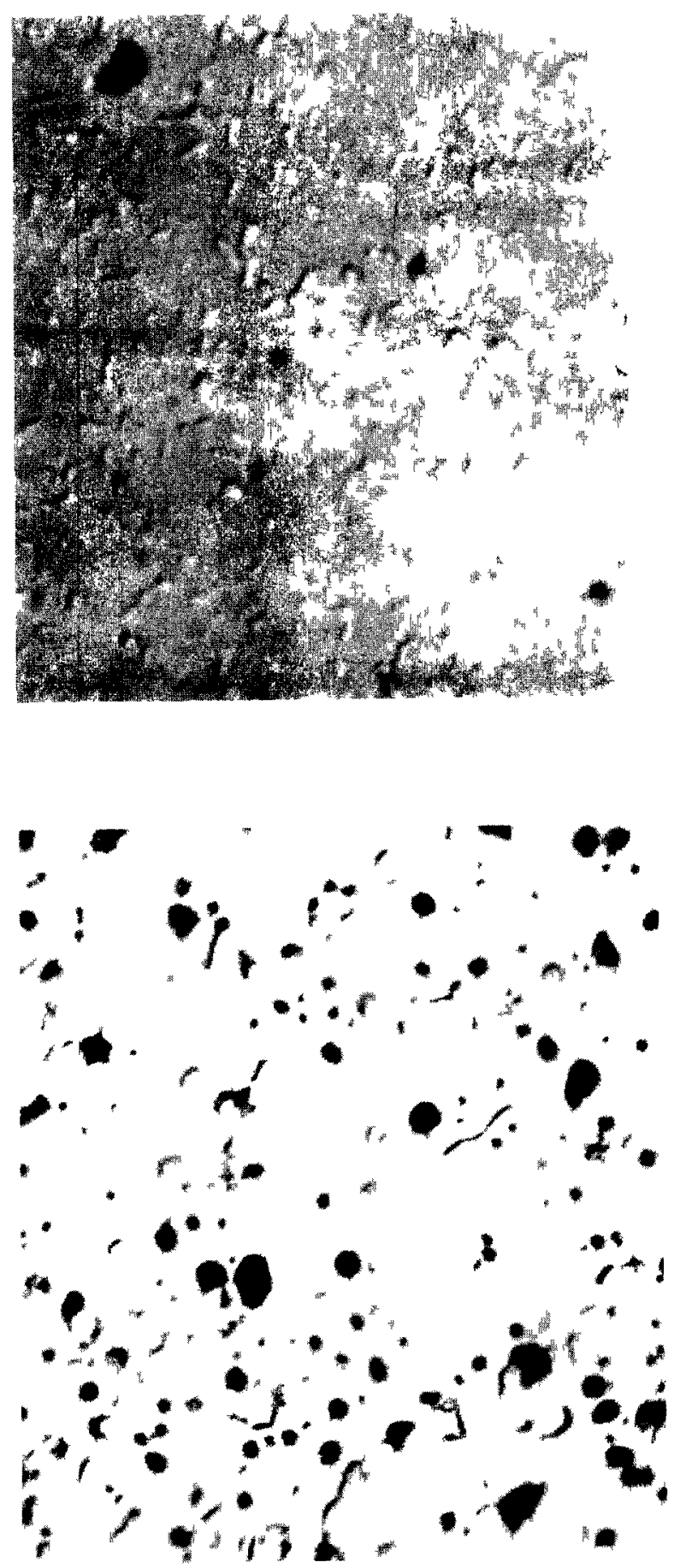

Figure 4. 8 wt \% U-Zr alloy, after 0.15 at.\% burnup and $500 \mathrm{hr}$ at $595^{\circ} \mathrm{C}$. As polished. (1000X)
Figure 3. 8 wt $\% \mathrm{v}-\mathrm{Zr}$ alloy, annealed $500 \mathrm{hr}$ at $595^{\circ} \mathrm{C}$. As polished. (1000X)

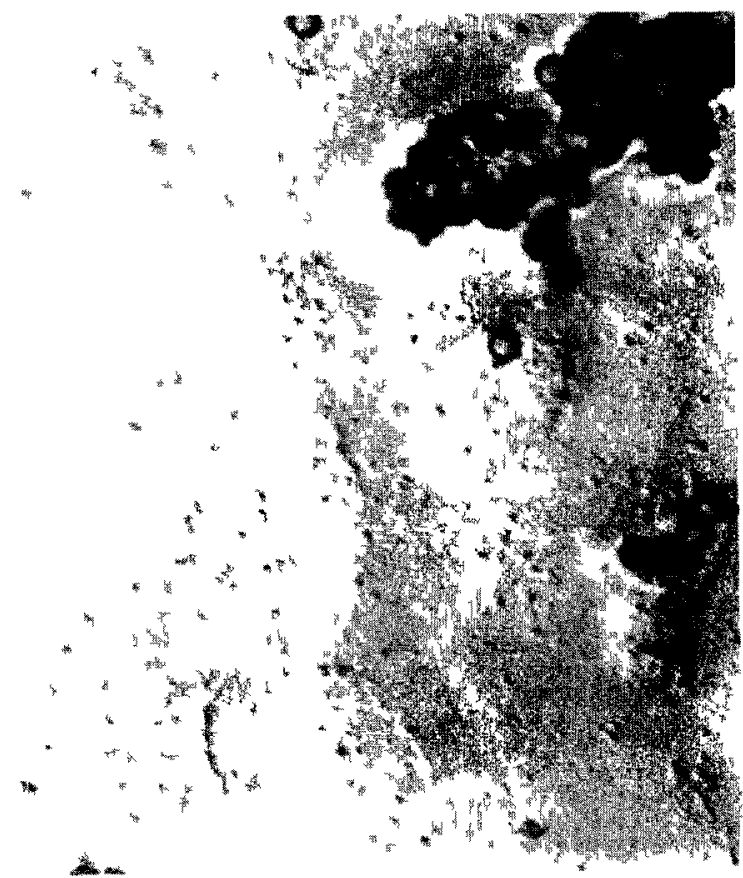

Figure 5. Carbon replica of 8 wt $\%$ U-Zr alloy, after 0.15 at. $\%$ burnup and $500-\mathrm{hr}$ anneal at $595^{\circ} \mathrm{C}$. As polished. $(10,000 \mathrm{X})$ 
Figure 6. 8 to U-Zr alloy, after 1.05 at.\% burnup and 500-hr anneal at $425^{\circ} \mathrm{C}$. As polished. (1000X)
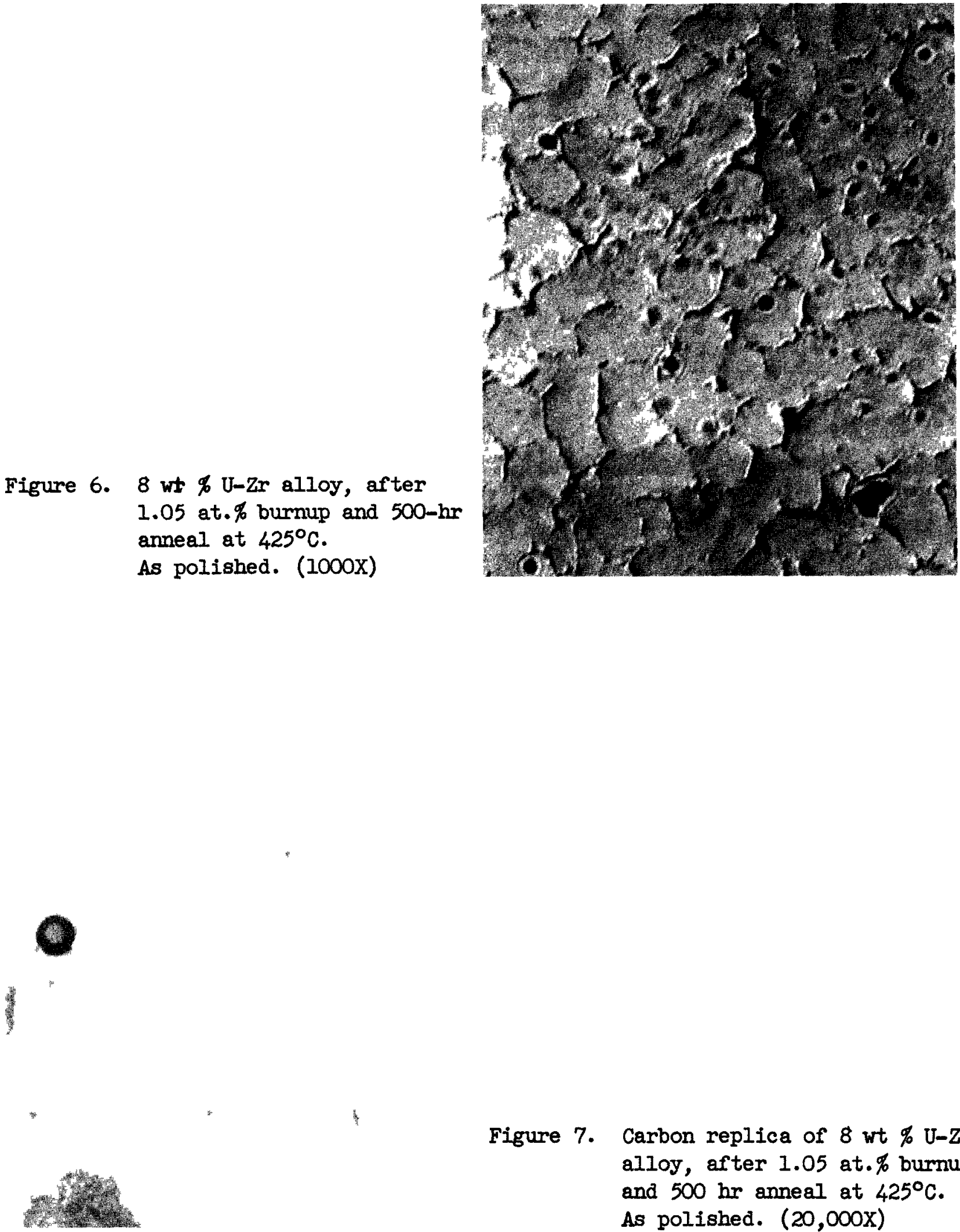

Figure 7. Carbon replica of 8 wt $\% \mathrm{U}-\mathrm{Zr}$ alloy, after 1.05 at.\% burnup and $500 \mathrm{hr}$ anneal at $425^{\circ} \mathrm{C}$. As polished. $(20,000 \mathrm{X})$ 

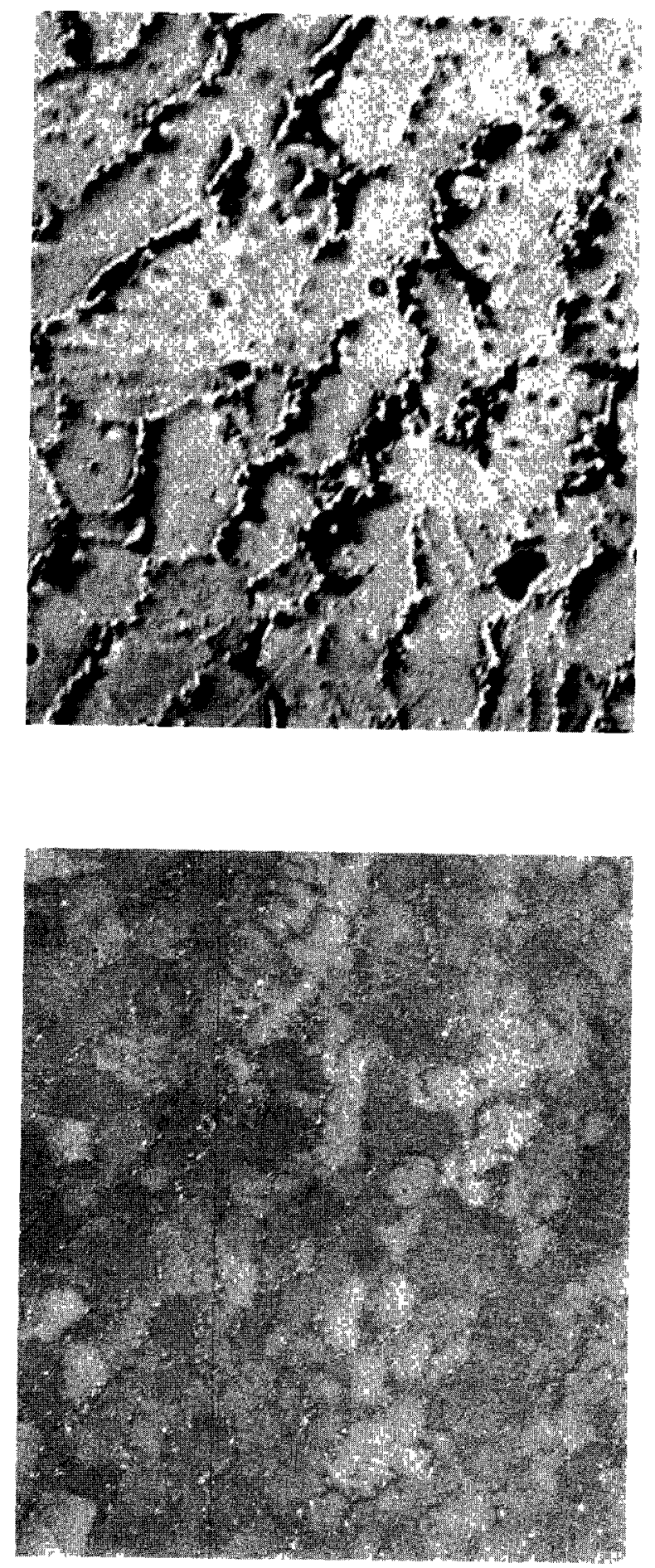

Figure 9. 8 wt \% U-Zr alloy, after 1.15 at.\% burnup and 500-hr anneal at $500^{\circ} \mathrm{C}$. As

polished. Polarized light; light spots are void spaces. (500X)
Figure 8. 8 wt \% U-Zr alloy, after 1.15 at.\% burnup and 500-hr anneal at $500^{\circ} \mathrm{C}$. As polished. (1000X)

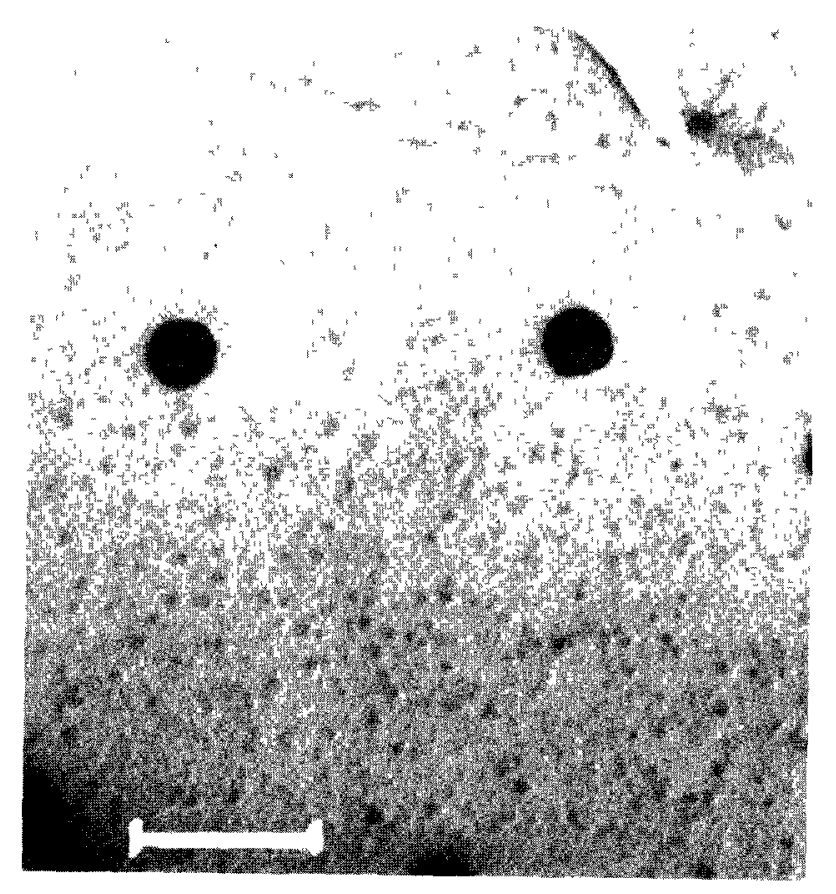

Figure 10. Carbon replica of 8 wt $\%$ U-Zr alloy, after 1.15 at. $\%$ burnup and $500 \mathrm{hr}$ at $510^{\circ} \mathrm{C}$. As polished. $(18,000 \mathrm{X})$ 
Figure 11. 8 wt \% alloy, after 1.25 at. $\%$ burnup and 500-hr anneal at $595^{\circ} \mathrm{C}$. As polished. (1000X) Large void areas.

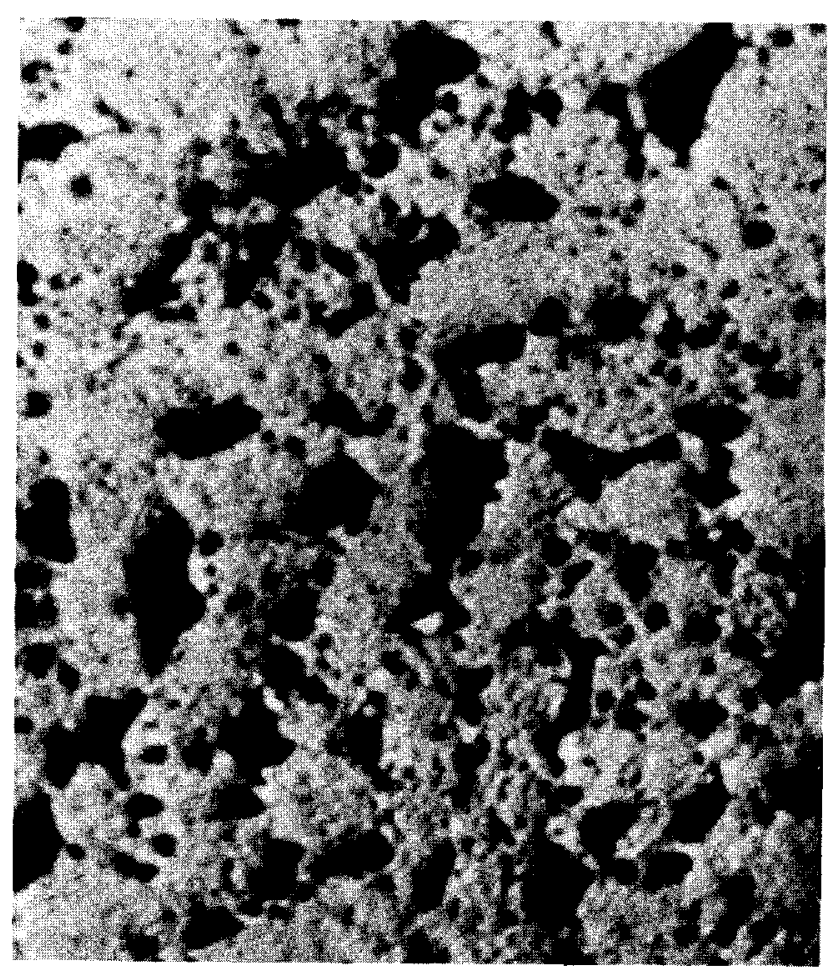

Figure 12. Carbon replica of $8 \mathrm{wt} \%$ U-Zr alloy, after 1.25 at.\% burnup and $500 \mathrm{hr}$ at $595^{\circ} \mathrm{C}$. As polished. $(37,000 \mathrm{X})$ 


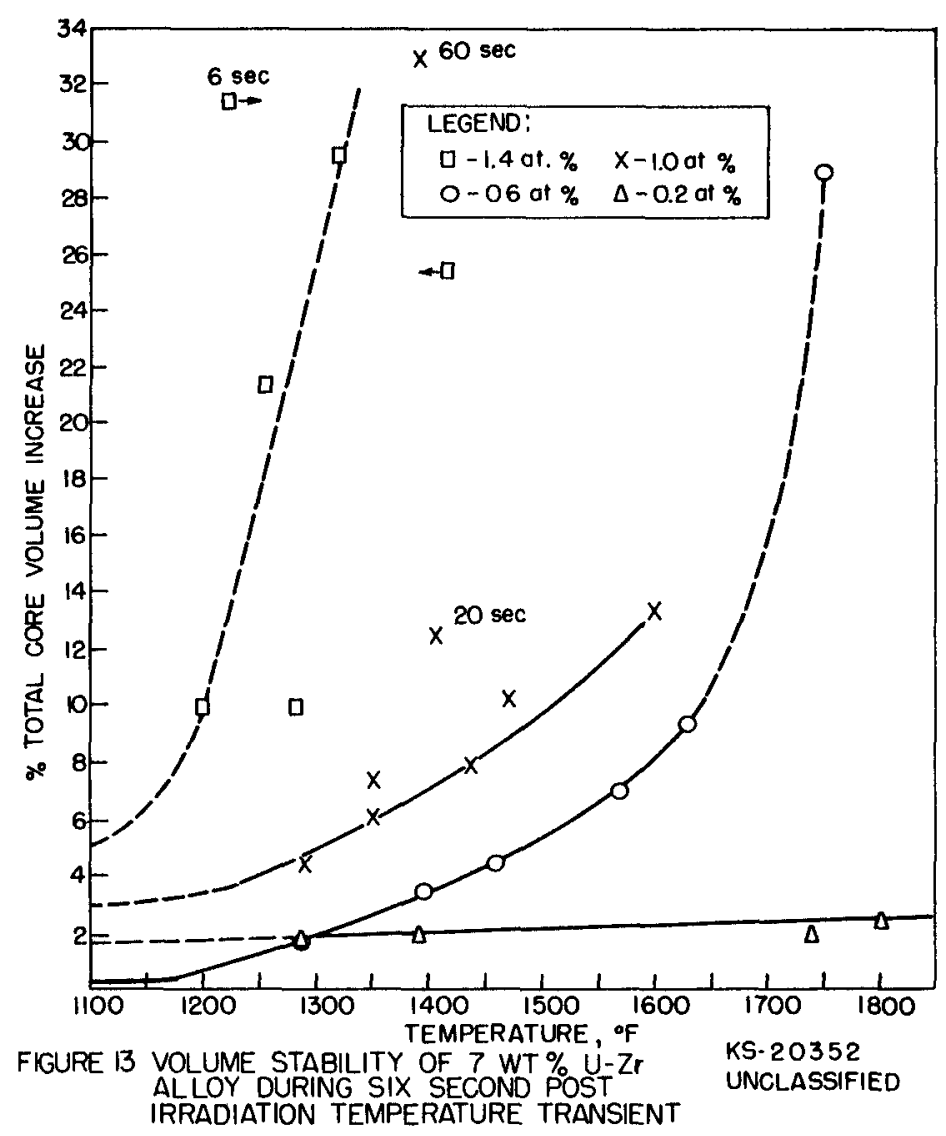

with a quench between each heating. The results show a strong dependence of the swelling on burnup. At very low burnup levels, the amount of swelling would be within acceptable levels even up to $1800^{\circ} \mathrm{F}$. As the amount of burnup increased through 0.6 and 1.0 , the maximum temperature for a given amount of swelling decreases. The detailed reason for the large differences in amounts of swelling of the 1.4 at.\% burnup material is not understood even though this is about the same amount of swelling observed in steady-state experiments just below this temperature.

The Zircaloy cladding had deformed in a ductile manner during these experiments. The material tends to go from an oval cross section to a round one. No length changes have been observed. 
sinealing at $950^{\circ} \mathrm{F}\left(510^{\circ} \mathrm{C}\right)$ for $150 \mathrm{hr}$ after the transients produced no further swelling although a shrinkage of up to $1.5 \%$ has been observed in sorme of the samples that swelled most during the transient. Thus, transients do not appear to produce any nulei which serve as sites for I uture growth. It seems probable, therefore, as will be discussed in the next section, that most of the gas has already precipitated into bubbles which grow during the transient by transformation or creep. Because of the burnup effects, limitations on transients cannot be established without recognition of the burnup present in the reactor at the time of the transient.

\section{CONCLUSIONS}

Ine volume changes and metallographic observations are consistent with the belief that a phase transformation is responsible for the large amounts of swelling a $620^{\circ} \mathrm{C}$ and that with increasing burnup this transformation occurs at lower temperatures. We are not yet in a position to decide whether the transformation is the expected one from delta phase to gamma or the reverse one, such as might be caused by phase reversal during irradiation. If the latter were the case, the reversion would have to occur very early in the irradiation before many fission products were present. The lowering of a transformation temperature with impurity additions (i.e., burnup) is a common occurrence in ordinary systems.

A different explanation 13 required to account for the saturation effects and the bubbles. In the United States where irradiation is usually done in the Materials Test Reactor at comparatively low temperatures and in high fluxes, gas-iniuced porosity 1 s almost never seen optically. The only apparent exceptions sccur with $U-Z r-B$ irradiations. The British, on the other hand, wo .. zve generally conducted their irradiations at lower fluxes, do observe bubbles or porosity in uranium and its alloys with the optical microscops. 3

R. S. Barnes ${ }^{4}$ has reported a series of experiments on the degradation of polymethylmethacrolate (Perspex) by thermal and radiation means in which the formation and growth of $\mathrm{H}_{2}$ gas bubbles were observed. He concluded that the number and size of the bubbles formed is proportional to $(F / D) 1 / 2$ where $F$ is fission rate and $D$ is diffusion rate. A. H. Willis, ${ }^{5}$ in approsching this problem theoretically, has found the same general dependency although he differs from Barnes somewhat on details. According to these ideas, bubble formation might be tho ght of as occurring in the following manner: Assume a very small amount or solubility, a high neutron flux or fission rate, anō a low temperature. Gas atoms thus produced will have a 
low diffusion rate and because of the high production rate will encounter one another through statistical fluctuations before they have individually swept out much volume. Because of the low solubility, a high degree of supersaturation is easily produced. According to the theories of precipitation, the higher the degree of supersaturation the smaller is the minimum critical nucleus size. For this reason many very small bubbles will be produced. Gas atoms subsequently produced will either form new bubbles or diffuse a short distance to an existing bubble. Iittle swelling will occur in spite of the gas precipitation because of the surface tension effect on the small bubbles. Postirradiation heating of the fuel to irradiation temperature or below should produce no changes. Heating to higher temperatures will produce swelling when pressure-volume-temperature effects in the bubbles overcome surface tension and matrix creep resistance. This further decreases the surface tension restraining force but also reduces the internal pressure. After some period of time a balance between these forces is obtained that results in a saturation of the swelling.

Irradiation at a high temperature in a low flux will produce different results. The volume swept out by a given atom will be much larger and the probability of a collision with a nucleating agent or already existing bubble will be greater and the degree of supersaturation less. Fewer and larger bubbles will be produced.

The carbon-shadowed Faxfilm replicas obtained from our samples contained $10^{14}$ to $10^{15}$ bubbles per cubic centimeter which were between 0.015 and $0.1 \mu$ in diameter. Bubbles of $0.04-\mu$ size, which appear to predominate, are calculated to retain gas at nearly 700 atm sressure by surface tension alone. Because the majority of the fission gases are collected in these voids and are not free to move around in the matrix, the calculation of diffusion rates based upon total gas concentration and ordinary diffusion distances does not appear to be realistic。

We have described annealing experiments on U-Zr alloy fuels that have recently been conducted at KAPL. Work is also being done on irradiated boron-containing material and on the uranium compounds and zirconium-base dispersion fuels described by A. P. Beard earlier at this conference. 


\section{REFERENCES}

1. H. A. Saller, F. A. Rough, A. A. Bauer, BMI 1092, May 1956;

J. F。 Duffy, C. A. Brunch, Trans. ADMVE 212, 17 (1958).

2. W. Vo Johnston, KAPL 1562, July 1956.

3. A. T. Churchman, R. S. Barnes, A. H. Cottrell, AERE M/R 2044, September 1956.

4. R. So Barnes, J. Nuclear Energy 5, 301 (1957).

5. A. H. Willis, A/Conf $15 / \mathrm{P} / 616$, Second International Conference on the Peaceful Uses of Atomic Energy, Geneva. 